\title{
Медведева О.Л.
}

\section{Проектная деятельность как средство формирования регулятивных универсальных учебных действий на уроках английского языка}

\author{
Medvedeva O.L. \\ Project activity as a mean of forming regulating \\ universal studying operations at English lessons
}

Основная цель статьи - изучить роль учебного проекта в формировании регулятивных учебных действий. В статье раскрываются термины «технология проектной деятельности», «регулятивные учебные действия». Данная работа основана на примере учебного проекта «Здоровый образ жизни»

Ключевые слова: технология проектной деятельности, регулятивные учебные действия

\section{Медведева Олеся Львовна}

Учитель, заместитель директора

Школа-интернат № 576 среднего общего

образования с углубленным изучением предмета

физическая культура

2. Санкт-Петербург, пер. Каховского, 2
The present article deals with the project activity as a mean of forming regulating universal studying operations at English lessons. The paper is based on the example of training projects "Healthy Lifestyle». The main purpose of this article is to study theoretic points of "technology of project activity», «regulating universal studying operations» and try to apply these knowledge in practice

Key words: technology of project activity, regulating universal studying operations

\author{
Medvedevs Olesya Lvovna \\ Teacher, Deputy Director \\ Boarding school №576 specializing in subject \\ physical education \\ Saint-Petersburg, Kahovskiy lane, 2
}

Основная цель современного образования - воспитание всесторонней развитой личности, умеющей самостоятельно мыслить, учиться, работать с информацией, самостоятельно совершенствовать свои знания и умения, приобретать новые знания. Одной из технологий, обеспечивающей личностноориентированное воспитание и обучение, является проектная деятельность, которая дает учителю возможность включить учащихся в реальное общение, насыщенное иноязычными контактами, опирающееся на исследовательскую деятельность, на совместный труд, и увидеть реальные результаты своего труда.

Вот что под учебным проектом подразумевает Е.С. Полат «Метод проектов всегда ориентирован на самостоятельную деятельность учащихся - индивидуальную, парную или групповую, которую учащиеся выполняют в течение определенного отрезка времени. Метод проектов всегда предполагает реше- 
ние какой-то проблемы, предусматривающей, с одной стороны, использование разнообразных методов, средств обучения, а с другой - интегрирование знаний, умений из различных областей науки, техники, технологии, творческих областей. Результаты выполненных проектов должны быть, что называется, «осязаемыми», т.е. если это теоретическая проблема, то конкретное ее решение, если практическая - конкретный результат, готовый к внедрению» $[1$, c.57].

Проекты, предназначенные для обучения языку, обладают как общими для всех проектов чертами, так и отличительными особенностями, среди которых главными являются следующие:

- использование языка в ситуациях, максимально приближенных к условиям реального общения;

- акцент на самостоятельной работе учащихся (индивидуальной и групповой);

- выбор темы, вызывающей большой интерес для учащихся и непосредственно связанной с условиями, в которых выполняется проект;

- отбор языкового материала, видов заданий и последовательности работы в соответствии с темой и целью проекта;

- наглядное представление результата.

Таким образом, проектно-исследовательская деятельность формирует различные виды универсальных учебных действий. Остановимся на регулятивных, т.к. для успешного существования в современном обществе человек должен обладать регулятивными действиями: уметь ставить себе конкретную цель, планировать свою жизнь, прогнозировать возможные ситуации, адекватно оценить уровень своих знаний и умений, найти наиболее простой способ решения задачи и прочее. Развитие всех этих умений обеспечивает проектная деятельность.

Приведем пример учебного проекта, который был проведен в общеобразовательной школе-интернате № 576 г. Санкт-Петербурга.

Название проекта: «Здоровый образ жизни»

Обоснование проблемы: тенденция к ухудшению здоровья школьников.

Актуальность проблемы: дефицит информации для школьников о правильном питании, режиме дня, психоэмоциональное здоровье.

\section{Цель проекта:}

- актуализировать знания учащихся о здоровом образе жизни;

- вызвать интерес учащихся к изучению английского языка и ведению здорового образа жизни;

- развить познавательную активность учащихся, расширить их кругозор;

Задачи проекта:

- познакомить учащихся с новыми лексико-грамматическими единицами по теме проекта;

- воспитать активную жизненную позицию и ответственное отношение к своему здоровью;

Тип проекта: информационно-творческий с элементами исследования. Форма проекта: коллективный. 
Предметно-содержательная область: межпредметный.

область исследования: английский язык, основы здорового образа жизни, физическая культура, биология.

Сроки проведения проекта: 2 недели.

\section{Участники проекта:}

- учителя английского языка;

- ученики 5, 8, 11 классов;

Работа над проектом проходила в 5 этапов:

1) поисковый

2) аналитический

3) практический

4) презентационный

5) контрольный

Самым важным для нас был поисковый этап, основная задача которого заинтересовать ребят и мотивировать на дальнейшую работу. Для этого мы предложили ребятам смоделированные ситуации, чтобы их подвести к определенной теме. На аналитическом этапе учащиеся под руководством учителя составили план работы над проектом и распределили обязанности. На следующем, практическом этапе участники проекта проводили социологическое исследование, результаты которого подтолкнули на сбор определенной научной информации и ее обработку. Следует отметить, что на этом этапе решались задачи по овладению знаниями в области английского языка:

- введение нового лексического и грамматического материала;

- работа с текстами;

- развитие навыков устной монологической и диалогической речи;

- развитие навыков письменной речи;

- развитие навыков аудирования;

- развитие логического мышления;

- развитие УУД.

Самым зрелищным был презентационный этап, на котором ребята показывали результаты своего труда: постеры, презентации, самодельные книги. На последнем этапе участники проекта давали оценки своему труду, высказывались о том, что получилось и, что вызвало трудности.

Причем, подготавливая свои работы, дети могли выбрать уровень выполнения задания: информативный, импровизационный или эвристический. Приятно отметить, что около 70\% учеников выбрали эвристический уровень. Таким образом, правильно подобранная система заданий и технология проектной деятельности привели к довольно высоким результатам.

Таким образом, использование проектной деятельности в образовательном процессе является частью большой работы по формированию регулятивных универсальных учебных действий. 
2. Краля Н.А. Метод учебных проектов как средство активации учебной деятельности учащихся. Омск: Изд-во ОмГУ, 2005. С. 123-126.

3. Полат Е.С. и др. Новые педагогические и информационные технологии в системе образования. М.: Академия, 1999. С. 57.

(C) 2015, Медведева О.Л.

Проектная деятельность как средство формирования регулятивных универсальных учебных действий на уроках английского языка
(C) 2015, Medvedeva O.L.

Project activity as a mean of forming regulating universal studying operations at English lessons 